\title{
The Effectiveness of Guess Tool Game to Teach Vocabulary to the Eighth Grade Students at MTs Negeri in OKU Timur
}

\author{
Zulaikah $^{1^{*}}$, dan Yunawati ${ }^{2}$ \\ 1,2 STKIP Nurul Huda Sukaraja \\ *Email: zulaikah@stkipnurulhuda.ac.id
}

\begin{abstract}
This article was experimental research, entitled "The Effectiveness of Guess the Tool Game to Teach Vocabulary to the Eighth Students at MTs Negeri in OKU Timur". The writer used true experimental design. The objective this study was "to find out whether Guess the Tool Game is effective or not to teach vocabulary to the Eighth Grade Students' at MTs Negeri in OKU Timur. The Populations were all eighth-grade students at MTs Negeri in OKU Timur with total number of 165 Students. The samples were class VIII.1 and class VIII.3. It divided into two class, experimental class and control class. The sample of this research was taken by using cluster random sampling. And independent t-test used for analyzing the data. Based on result analysis, $t$ obtained mean differences between post-test of experimental class and post-test of control class. From the analyzing the data, and obtained the t-obtained was higher than critical value of t-table. For t-obtained 4.83 and t-table was 1.999. Therefore, the null hypothesis $(\mathrm{Ho})$ was rejected and alternative hypothesis (Ha) was accepted. It meant that the use of Guess the Tool Game was effective to teach vocabulary to the eighth-grade students at MTs Negeri in OKU Timur.
\end{abstract}

Keywords: Guess the Tool Game, Vocabulary, Teaching.

\section{INTRODUCTION}

English is one of language that have important role in this era. Many people used and learned English as their second language. In Indonesia, English is foreign language that has been learned from the first stage of the school until the university Anisa (2010). English was taught as main lesson in formal education. Moreover, now English was taught as one of the important lesson in the curriculum, Isnaeni (2014).

The goals in teaching English are the students can master all of English elements. They are vocabulary, pronunciation, grammar, and reading. In understanding English well, the students have to master four skills that are essential for the purpose of communication, they are listening, speaking, reading and writing, Saleh, (1992).

Vocabulary is the basic part and a key element to learn any language. Teaching vocabulary through the use of games has become crucially important for English language learners because they sustain enjoyment and interest in learning and encourage using the language in a fearless and creative manner, Bakhsh (2016). Vocabulary is the most important aspect to support the four language skills. Cameron (2002) says that vocabulary has become center stage in foreign language teaching. Because vocabulary is the first stage to learn a language, without vocabulary students cannot understand a language well.

In this era, many teachers modify the learning process in more innovative and interesting way. Nowadays, teaching English has been growing very rapidly all over the world, including in Indonesia. There many kinds of technique to teach vocabulary that can be used by the teacher. Teacher should be able to use appropriate method or technique to teach vocabulary that can make learning English is more innovative.

According to Reni Triana (2006) many students have goten difficulties in remembering the words, because they are quite different from their daily language, that is why learning vocabulary is not easy for them. Besides, the teachers rarely relate vocabulary teaching to needs of the students and the environment of the students themselves as well. 
According to Brewster and Ellis (2002:27), games are not only motivating and fun but also provide exellent practice for improving vocabulary, pronunciation, gammar and four laguage skills. For this game the teacher puts two students in pair, facing each other, and gives a card with two words written on it to each student and asks them not to show each other their cards. The two words written on the cards are a tool and a related occupation. One at time, each student describes the tool without saying its name. The other students have to guess the tool and name an occupation that uses the tool.

By using Guess the Tool Game, teacher would gave cues of word order and begin the learning using game and it made students more attentive. It can cover the problems above and make the students are more enjoyable to learning English. Furthermore, the object of this research are to find out whether or not there is significant difference between the students who are taught vocabulary by using guess the tool game and students who are not taught by using conventional strategy at Eight Grade Students of MTs Negeri in OKU Timur

\section{METHOD}

From this research the method was used true experimental design. The design involves experimental class and control class. The experimental class that has give a treatment and control class used conventional method. This research took the eight students of MTs Negeri in OKU Timur as population of the research. The total number populations were 165 students from five classes. It could be seen in table 1.

Table 1. The Population of The Research
\begin{tabular}{lll}
\hline No & Grade & Total \\
\hline 1 & Grade of VIII.1 & 32 \\
2 & Grade of VIII.2 & 34 \\
3 & Grade of VIII.3 & 32 \\
4 & Grade of VIII.4 & 33 \\
5 & Grade of VIII.5 & 34 \\
\hline Total & 165 \\
\hline
\end{tabular}

Source: MTs Negeri in OKU Timur

The technique used the cluster random sampling to take the sample. For this research, Cluster random sampling was the easiest way to take a sample. Because in Cluster random sampling was chose based on the class or group, not individually. The sample of this study consist could be seen in the following table 2 .

Table 2. The Sample of The Research

\begin{tabular}{lll}
\hline Group & Grade & Total \\
\hline A (experimental class) & VIII.1 & 32 \\
B (control class) & VIII.3 & 32 \\
\hline Total & & 64 \\
\hline
\end{tabular}

Source: MTs Negeri in OKU Timur

In this research gave two tests to get an objective data. They were the pre-test and post-test and need six meetings in the class. For the first meeting, it used for the pre-test. Then, four times were giving treatment in the experimental class. Finally, the post-test in the last meeting to the students. This reaearch used written test. The test was list of the question in multiple choice form. The test consisted of twenty items. The scoring was each items, for correct answer was 1 (one) and the incorrect was 0 (zero).

To keep the result of this research to be good, so all of the intruments would be test. First, the validity of the research instrument, used the content validity. In this research prepared 20 questions by using multiple choice.

Second, test reliability used KR21 formula. KR21 will use to estimate the reliability of the test. The following is Kuder-Richardon 21 (KR21), formula as shown below: 


$$
\mathrm{KR} 21=\frac{\mathrm{K}}{K-1}\left[1-\frac{\mathrm{M}(K-\mathrm{M})}{K(\mathrm{SD})^{2}}\right]
$$

Where:

$\mathrm{KR}-21=$ Kurder Richardson correlation coefficient.

$\mathrm{K}=$ Number of items in the test.

$\mathrm{M} \quad=$ The average of scores

$\mathrm{SD}=$ Standard Deviation

To find out the Standard deviation of the test score, the writer was used the formula bellow:

$$
S D=\sqrt{\frac{\sum\left(x i-x^{-}\right)^{2}}{(N-1)}}
$$

Which:

$\mathrm{xi}=$ Individual score

$x^{-}=$Value of mean

$\mathrm{N}=$ The Number of Students

From the formulation above, the result of the reliability of the test was 0.72 . According to Fraenkel and Wallen (1993:49) "The reliability index should be at least 0.70 or preferably higher. The reliability index was 0.72 . it was higher than 0.70 . It meant that the vocabulary test was reliable and consistent. Then, In analyzing data, this research used $t_{\text {test }}$ to know whether Guess the Tool Game could increase students' Vocabulary ability or not. Before the writer used independent t-test for analyzing the data, the writer would use conversation of predicate of the test. To get students' score of vocabulary mastery by using Guess the Tool Game, used the following formula:

$$
s=\frac{x}{q} X 100
$$

Where:

$\mathrm{s}:$ Student score

$x$ : Number of right answer

$q$ : Number of items

Source: Sudijono, 43-44:2

For this reseacrh used conversion of percentage range to present students' score. It described the students' score that can be gain at doing a test. It will explain in thistable:

Table 3. The conversion of the presented range

\begin{tabular}{ll}
\hline Score Interval & Category \\
\hline $86-100$ & Excellence \\
$71-85$ & Good \\
$56-70$ & Average \\
$41-55$ & Poor \\
$0-40$ & Failed \\
\hline
\end{tabular}

(Arikunto, 2002:87)

The data from the test was analyzed by using independent test. According Sugiyono (2010:138) to know significant difference between the scores in the post-test of experimental class and the scores in the post-test of control class, the independent test can be applied: 
$t=\frac{X_{1}-X_{2}}{\sqrt{\frac{\left(n_{1}-n_{2}\right) s_{1}^{2}+\left(n_{2}-1\right) s_{2}^{2}}{n_{1}+n_{2}}\left(\frac{1}{n_{1}}+\frac{1}{n_{2}}\right)}}$

Which:

$\mathrm{t}=$ Independent $\mathrm{t}$-Test

$X_{1}=$ Average Score of Experimental Class

$X_{2}=$ Average Score of Control Class

$S_{1}=$ Standard Deviation of Experimental Class

$S_{2}=$ Standard Deviation of Control Class

$s_{1}^{2}=$ Variant of Experimental Class

$s_{2}^{2}=$ Variant of Control Class

$n_{1}=$ Number of Students of Experimental Class

$n_{2}=$ Number of Students of Control Class

Source: Sugiyono, 2010:318

Formula of standard deviation:

$$
S D=\sqrt{\frac{\sum\left(x i-x^{-}\right)^{2}}{(n-1)}}
$$

Which:

$\mathrm{SD}=$ Standard deviation

$\mathrm{xi}=$ Individual score

$x^{-}=$Value of mean

$\mathrm{n}=$ Number of students

Source: Sugiyono, 2010:57

Formula of Variant:

$$
s^{2}=\frac{\sum(x i-x)^{2}}{(n-1)}
$$

Which:

$s^{2}=$ Variant

$\mathrm{xi}=$ Individual score

$x^{-}=$Value of mean

\section{RESULT AND DISCUSSION}

In this section, the writer presents the findings of the research that was already done.in this findings segment, explained the result of the research.

\section{The Pre-test of experimental Class}

After the pre-test was given to the experimental group, it was found that the biggest score was 80 , the lowest score was 35 , mean was 59.37 , median was 60 and modus was 60 . After that calculated the range of this test. To find the range as result bellow:

Range $=$ highest Score - Lowest Score

Range $=80-35$

Range $=45$ 


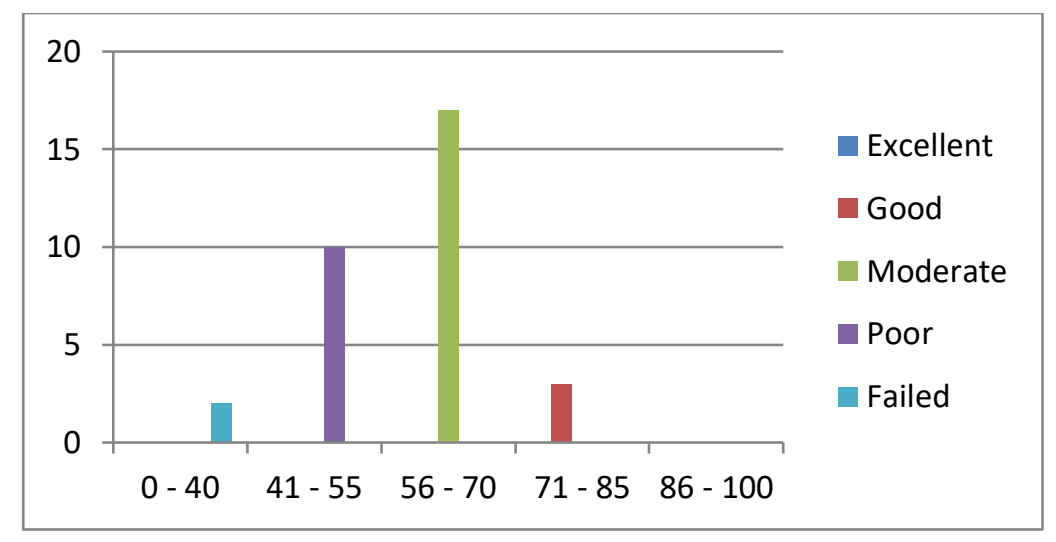

Figure1.The Score Distribution Of Experimental Class Pre-Test

In the Figure 1 The Score Distribution Of Experimental Class Pre-Test above There was no student who got excellent criteria, 3 students $(9.38 \%)$ who got good criteria, 17 students $(53.13 \%)$ who got moderate criteria, 10 students $(31.25 \%)$ who got poor criteria, and 2 students $(6.25 \%)$ who got failed criteria. The minimum score was 35 . The average score was 59.37 from 32 students in the pre-test.

\section{The Post-test of Experimental Group}

After the post-test was given the experimental class, it was found that highest score was 95, the lowest score was 50 , median was 70 , and modus was 70 . after that tried to find the range of this test. The formula was used to get the range this formula :

Range : Highest Score - Lowest Score

Range : $95-50$

Range : 45

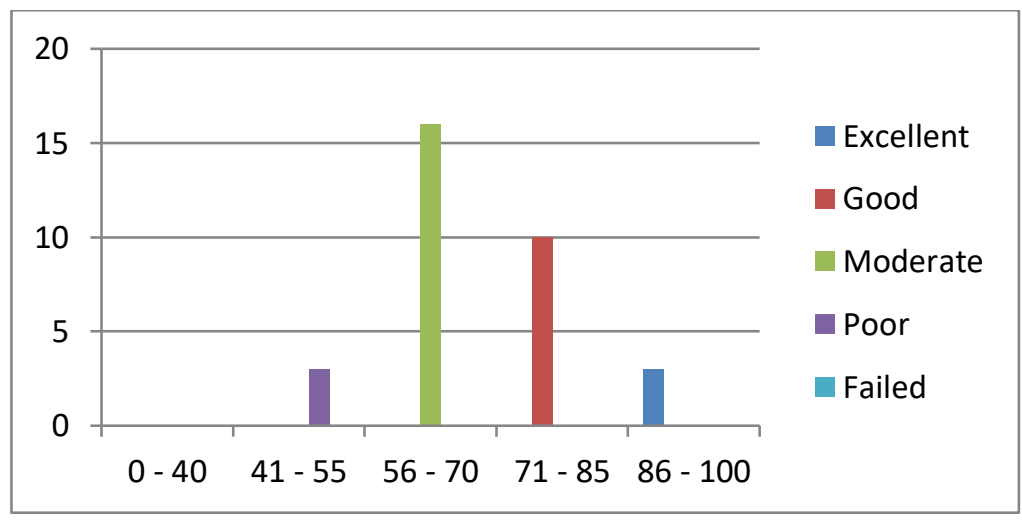

Figure 2. The Score Distribution Of Experimental Class Post-Test

In the Figure 2 The Score Distribution Of Experimental Class Post-Test above there were 3 students $(9.38 \%)$ who got excellent criteria, 10 students $(31.25 \%)$ who got good criteria, 16 students $(50 \%)$ who got moderate criteria, 3 students $(9.38 \%)$ who got poor criteria, and 0 student who got failed criteria. Mean was 72.5 from 32 students in the post test.

\section{The Pre-test Result of Control Group}

After the pre-test given was to control group, it was found that the highest score was 75 , the lowest was 35, median was 60 and modus was 60 . After that tried to find the range of this test. The formula was used to get the range. This is the formula:

Range $=$ Highest Score - Lowest Score

Range $=75-35$ 
Range $=40$

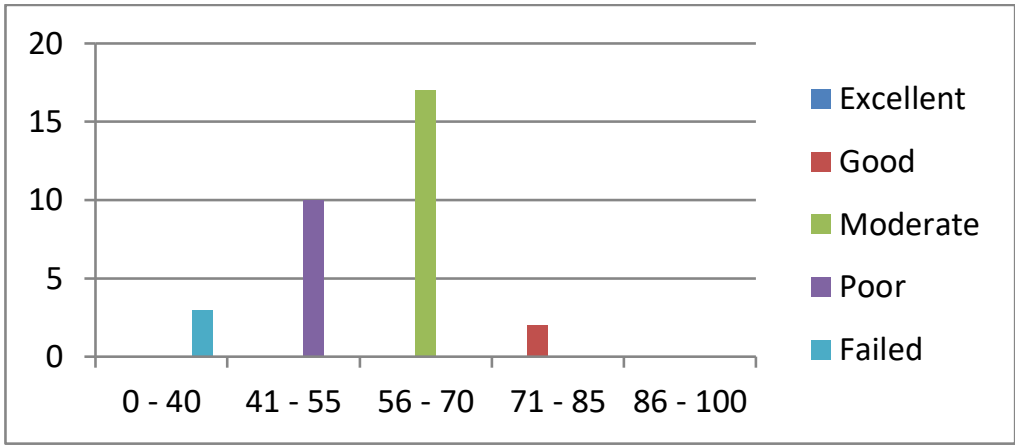

Figure 3. The Score Distribution Of Control Class Pre-Test

In the Figure 3 The Score Distribution Of Control Class Pre-Test above there was no student who got excellent criteria, 2 students $(6.25 \%)$ who got good criteria, 17 students $(53.13 \%)$ who got moderate criteria, 10 students $(31.25 \%)$ who got poor criteria, and 3 students $(9.37 \%)$ who got failed criteria. The minimum score was 35 the average score was 57.97 from 32 students in the pre-test.

\section{The Post-test Result of Control Class}

After the post-test was given to the control group, it was found that the highest score was 85 , the lowest score was 40 , median was 67.5 , and modus was 70 . After that tried to find the range of this test. The formula was used to get the range. This is the formula:

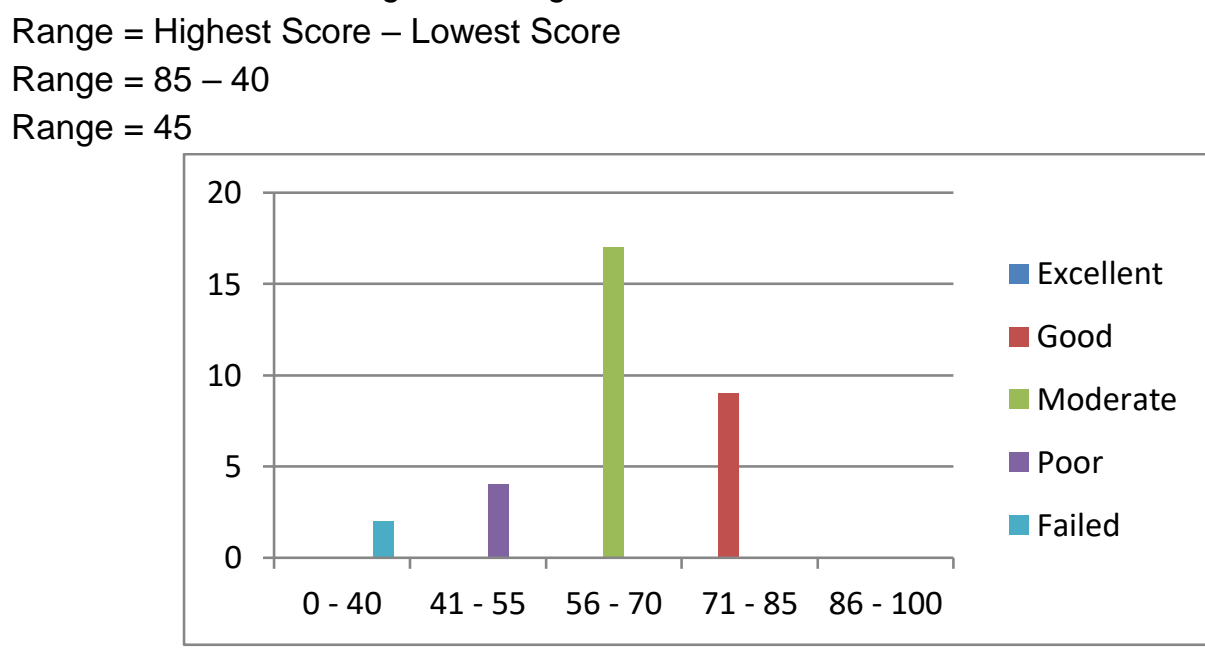

Figure 4. The Score Distribution Of Control Class Post-Test

In the Figure 4 The Score Distribution Of Control Class Post-Test above there was no student who got excellent criteria, 9 students $(28.13 \%)$ who got good criteria, 17 students $(53.13 \%)$ who got moderate criteria, 4 students (12.5\%) who got poor criteria, and 2 students $(6.25 \%)$ who got failed criteria. The minimum score was 40 the average score was 57.97 from 32 students in the pre-test.

The result tabulation of data from statistic can discribe that, the value of t-obtained was 4.83 , with the degree of freedom (df) $n_{1}+n_{2}-2=32+32-2=62$ and $95 \%$ or 0.05 significance level for two-tailed test, the critical value in the t-table was 1.999 . Since the $t_{\text {obtained }}$ was higher than critical value in the t-table, it meant that there was any significant difference achievement between experimental class that was taught by guess the tool game and control class that was taught by using conventional method.

Based on statistical analysis in findings above, it was known that the students' score of experimental class has increased, it could be proved by comparing the students' pre-test and students' post-test of students' score was increased after they got treatment in the class. Based on 
findings, the writer obtained student's score of pre-test of experimental class was 75 and student's score of post-test of experimental class was 95. It was shown that, the applying of guess the tool game as treatment was gave an increasing in student's vocabulary. It has influence in the learning which guess the tool game can make students easy to accept the material, they also can memorize it with pleasure.

From the result of statistical analysis for experimental class, mean of students' pre-test was 59.37 and mean of students' post-test was 72.5 . It was increased $13.13 \%$ and the students' score of post-test in experimental class and control class was higher than the critical value of $t$-table $(4.83>1.999)$. Consequently, the alternative hypothesis $(\mathrm{Ha})$ was accepted and the null hypothesis (Ho) was rejected. So, it could be concluded that teaching Vocabulary by using guess the tool game at the eighth grade students at MTs Negeri in OKU Timur was effective.

\section{CONCLUSIONS}

Based on result of the study, took some conclusions as follows; There was significant difference of the students' test before and after were taught by using guess the tool game at MTs Negeri in OKU Timur. Then There was a significant difference of the test score between the students' were taught using game and the students were taught by using conventional method. Next The result of t-obtained students' score of post-test in experimental class and control class was higher than critical value of t-table $(4.83>1.999)$. This statistical evidence approved that the alternative hypothesis (Ha) was accepted and null hypothesis was rejected. So, it could be concluded that teaching vocabulary by using guess the tool game is significantly effective to the eighth-grade students at MTs Negeri in OKU Timur.

\section{ACKNOWLEDGEMENT}

Thank you very much for the Chairman of STKIP Nurul Huda Sukaraja,A chief of LPPM STKIP Nurul Huda, the member of Journal Titian IImu STKIP Nurul Huda Sukaraja, the head master of MTs Negeri in OKU Timur and don't forget all of the lecturer at STKIP Nurul Huda Sukaraja.

\section{REFERENCES}

Anisa,I. (2011). Improving students' vocabulary mastery using experiential learning. Retrieved from https://eprints.uns.ac.id.

Arikunto, S. (2002). Prosedu rPenelitian Suatu Pendekatan Praktis. Jakarta: Rineka Cipta.

Bakhsh, S. A. (2016). Using games as a tool in teaching vocabulary to young learners. English Language Teaching, 9(7), 120.https://doi.org/10.5539/elt.v9n7p120.

Brewster, J and Ellin, G. 2002. The Primary English Teacher's Guidance. New Edition. London: Pinguin English.

Cameron, L. (2002). Teaching languages to young learners. Cambridge: Cambridge University Press.

Fraenkel, R Jack and Norman e Wallen. (1990). How to Design and Evaluate Research in Education. Newyork: NY: MCGraw Hill inc.

Fraenkel, R Jack and Norman e Wallen. (1993). How to Design and Evaluate Research in Education. Newyork: NY: MCGraw Hill inc. 
Isnaeni, (2014). Pembelajaran Bahasa Inggris di Sekolah / Madrasah. Retrieved from https://suaraguru.wordpress.com/

Saleh,Y. (1992). Methods of Teaching English as a Foreign Language: Fundamental of Language Teaching for Indonesia Teachers of English. Palembang: Faculty of Teacher Training and Education. University of Sriwijaya.

Sugiyono, (2010). Statistikauntuk Penelitian. Bandung: Alfabeta.

Triana, R. (2006). Teaching Vocabulary in the Theme of Banking Through Meaningful Drills to The Tenth Grade Students of SMK Swakarya Palembang. Palembang: Faculty of Teacher Training and Education University of PGRI Palembang. 